\title{
DERMATOGLYPHIC STUDY OF BETA THALASSEMIA IN A TERTIARY CARE HOSPITAL - A CASE CONTROL STUDY
}

\begin{tabular}{|l|l|l|l|l|l}
\hline Anatomy &
\end{tabular}

Dr. Oindrila Senior Resident, Department Of Anatomy, Raiganj Government Medical College And Chhatui Hospital, Raiganj, Uttar Dinajpur, West Bengal, India.

\section{Dr. Pranab}

Mukherjee*

Professor And Head Of The Department Of Anatomy, Malda Medical College, Malda,

Dr. Premananda

Bharati

\section{Dr. Debarshi jana}

\begin{abstract}
BACKGROUND: The term "thalassemia" was coined by Whipple and Bradford in 1932, in their classical paper of pathology of the condition. Thalassemia is a heterogenous group of genetic disorder affecting haemoglobin synthesis which results from a reduced rate of production of one or more globin chains of haemoglobin.

AIM: The current study will try to find out the dermatoglyphic correlation between thalassemic children and children not having thalassemia in respect of gender as well as bilateral asymmetry.

METHODS: The sample for the present case control study was collected from Thalassemia unit, under Paediatric department at R.G. Kar Medical College and Hospital, Kolkata. Among 204 individuals- 102 are cases, who are diagnosed Beta Thalassemia patients up to 12 yrs of age and 102 are normal children upto $12 \mathrm{yrs}$ of age taken as control groups. Among 102 in each case and control groups, 51 are male and 51 are female individuals.

RESULT: Association of control male and Beta thalassemic male vs. Triradial count right was statistically significant ( $\mathrm{p}<0.0001)$. Association of control male and Beta thalassemic male vs. Triradial count left was statistically significant $(\mathrm{p}<0.0001)$.

CONCLUSION: In female thalassemia patients, there was complete absence of radial loops. But, significant lower incidence of radial loops of left hand was observed in male Beta thalassemics than the control group.
\end{abstract}

\section{KEYWORDS}

Beta Thalassemia, paediatric, children, dermatoglyphic.

\section{INTRODUCTION}

Dermatoglyphic is a term originating from a greek word (Derma=Skin Glyphics = Curving). It is a scientific study of epidermal ridges and their configuration on palmar and plantar region. These fine patterned epidermal ridges are unique for an individual. They are formed early in foetal life under genetic control and remain unchanged throughout the life.

During $3^{\text {rd }}$ and $4^{\text {th }}$ month of intrauterine life dermatoglyphic configuration is differentiated in their definitive form and by $7^{\mathrm{m}}$ month of gestation their development is completed. These dermal ridge configurations are permanent and are inherited. It forms an important diagnostic tool in the field of anthropology and human population genetics.

Dermatoglyphics is a branch of science which deals with the study of fine patterned epidermal ridges on digits, palms, soles and toes.

Dermatoglyphics is useful tool for detecting specific syndromes of genetic origin.Significant certain dermatoglyphic patterns have been established by many researchers in genetic disorders like Mongolism, Turner's syndrome, Klienfelter's syndrome. Hence it can be said that dermatoglyphics shows definitive diagnostic variations for those disorders which have genetic basis.

The importance of dermatoglyphics lies in its unique character in each and every individual and also that it differs in monozygotic twins ${ }^{1}$. The dermatoglyphic pattern in Down s syndrome (Trisomy 21) was discovered by Cummins in $1936^{2}$. Medical disorders which are genetically related may be studied with the help of dermatoglyphics. This is a safe and atraumatic procedure which doesnot require any expensive equipment.

Thalassemia is the most common single gene disorder and autosomal recessive pattern of inheritance. A widely prevalent disease of India ${ }^{3}$. Most common in Mediterranean countries, part of Africa and southeast Asia. The first clinical description of thalassemia was given by Dr. Thomas B. Cooley ${ }^{4}$, an American pediatrician. Previously, the disorder was known to be splenic anemia, erythroblastosis or Mediterranean anemia. His description was almost certainly Beta thalassemia.

Thalassemia can be classified into alpha, beta, delta, delta-beta depending upon which chain of haemoglobin molecule is affected. Beta thalassemia is one of the most significant single gene disorders globally. It is a major health problem worldwide. Throughout the world, dermatoglyphics was a helpful tool for the diagnosis of betathalassemia patients. About $10 \%$ of the total world thalassemia patients, belong to Indian subcontinent. Among them, 3\% - 4\% are the carriers. In India, the disorder is highly prevalent in northern, western and eastern parts. Beta- thalassemia is a major genetic disorder observed in West Bengal.

Hence, the current study has been undertaken to compare dermatoglyphic configurations between cases of Beta thalassemia and controls, inorder to findout the correlation and to provide an anatomic sign for early diagnosis of the disorder.

\section{AIMS \& OBJECTIVES}

The current study will try to find out the dermatoglyphic correlation between thalassemic children and children not having thalassemia in respect of gender as well as bilateral asymmetry. Dermatoglyphic study of thalassemia among Bengali population has not sufficiently done till date. The research hypothesis is to find out a relation between palmar dermatoglyphic patterns and Beta thalassemia to make a provisional diagnosis of the disease.

\section{OBJECTIVE OF RESEARCH}

\section{GENERAL:}

1. To study dermatoglyphic patterns of fingers and palms in patients of Beta thalassemia.

2. To correlate dermatoglyphic patterns between thalassemic children with children not having thalassemia.

3. To establish effectiveness of dermatoglyphics as inexpensive, noninvasive,anatomical baseline diagnostic tool for Beta thalassemia.

\section{SPECIFIC:}

1. To compare qualitative and quantitative dermatoglyphic characteristics in Beta thalassemia patients with children not 
having Beta thalassemia( control group).

2. To study whether there are any sex wise difference of dermatoglyphic characteristics in Beta thalassemia patients and matched control group.

3. To study bilateral asymmetry of dermatoglyphics in patients of Beta thalassemia with matched control group.

\section{MATERIALS AND METHOD}

The sample for the present case control study was collected from Thalassemia unit, under Paediatric department at R.G. Kar Medical College and Hospital, Kolkata. The detailed analysis of palmar and finger printing and the data interpretation was done in the Department of Anatomy,R.G. Kar Medical College and Department of Anthropological Biology,Indian Statistical Institute.

Among 204 individuals- 102 are cases, who are diagnosed Beta Thalassemia patients up to 12 yrs of age and 102 are normal children upto $12 \mathrm{yrs}$ of age taken as control groups. Among 102 in each case and control groups, 51 are male and 51 are female individuals.

STUDYAREA: Dermatoglyphic study done in :

1. R.G.Kar Medical College,Kolkata,West Bengal

$\sim$ Department of Anatomy

$\sim$ Thalassemia unit under Paediatric Department

2. Indian Statistical Institute, 203 B.T. Road, Kolkata

$\sim$ Department of Biological Anthropology Unit

STUDY POPULATION: Total population was divided into two groups:

1. Diagnosed (by HPLC) thalassemia patients admitted in Paediatric Department.(In R.G. Kar Hospital, patients are admitted up to 12 years under Paediatric department.So, in this study thalassemia patients upto 12 yrs of age are taken.)

2. Children not having thalassemia(gender matched control group upto 12 yrs of age)from department of Paediatrics of R.G. Kar Medical College and Hospital.

STUDY PERIOD: Over a period of twelve months(one year) approximately.

STUDY DESIGN: A hospital based, case control study consisting of Beta thalassemia major patients (diagnosed by High Performance Liquid Chromatography) and its matched control group. In order to use dermatoglyphic characteristics as a diagnostic tool to detect thalassemia patients, it is required to know that distinct dermatoglyphic characteristics should differ among thalassemia group and normal control group.

\section{INCLUSION CRITERIA:}

Diagnosed Beta thalassemia patients up to $12 \mathrm{yrs}$ age with relevant hematologic evidence - selected as cases. (In R.G. Kar Hospital, patients upto $12 \mathrm{yrs}$ under paediatric department. So, in this study thalassemia patients up to 12 yrs of age are taken.)

Normal children up to 12 yrs of age without any hemoglobinopathy and positive family history of hemoglobinopathy will be selected as control group.

\section{EXCLUSION CRITERIA:}

Any burns, injuries, deformities involving fingers and palms; Patients with any other genetic or hereditary disorders.

SAMPLE SIZE: Total study population is 204. It is divided into:

1. 102 Cases $($ Male $=51$, Female $=51)$

2. 102 Controls $($ Male $=51$, Female $=51)$ PARAMETERS TO BE

STUDIED : QUALITATIVE PARAMETERS: Arches, Loops- radial and ulnar, Whorls.

\section{RESULT AND ANALYSIS}

Our study showed that association of control and Beta thalassemia vs. a - b Ridge count right was statistically significant $(p<0.0001)$. Association of control and Beta thalassemia vs. a - b Ridge count left was not statistically significant $(\mathrm{p}=.669)$. Association of control male and Beta thalassemic male vs. a - b Ridge count right was statistically significant $(\mathrm{p}=.004)$. Association of control male and Beta thalassemic male vs. a - b Ridge count left was statistically significant $(p=.001)$.

It was found that association of control and Beta thalassemic female vs. a - b Ridge count right was statistically significant $(\mathrm{p}<0.0001)$. Association of control and Beta thalassemic female vs. a - b Ridge count left was statistically significant $(p=.008)$. Association of control female and Beta thalassemic male vs. a - b Ridge count right was statistically significant $(p<0.0001)$. Association of control female and Beta thalassemic male vs. a - b Ridge count left was not statistically significant $(\mathrm{p}=.669)$

We found that association of control and Beta thalassemia vs. Triradial count right was statistically significant $(\mathrm{p}<0.0001)$.Association of control and Beta thalassemia vs. Triradial count left was statistically significant $(\mathrm{p}<0.0001)$. Association of control male and Beta thalassemic male vs. Triradial count right was statistically significant $(p<0.0001)$. Association of control male and Beta thalassemic male vs Triradial count left was statistically significant $(\mathrm{p}<0.0001)$.

It was found that association of control female and Beta thalassemia in female vs. Triradial count right was statistically significant $(p=.018)$.Association of control female and Beta thalassemia in female vs. Triradial count left was statistically significant $(p<0.0001)$. Association of control female and Beta thalassemic male vs. Triradial count right was statistically significant $(p<0.0001)$.Association of control female and Beta thalassemic male vs. Triradial count left was statistically significant $(\mathrm{p}<0.0001)$.

We observed that association of control and Beta thalassemia vs. Palmar atd angle right was statistically significant $(\mathrm{p}<0.0001)$. Association of control and Beta thalassemia vs. Palmar atd angle left was statistically significant $(\mathrm{p}<0.0001)$.Association of control male and Beta thalassemic male vs. Palmar atd angle right was statistically significant $(\mathrm{p}<0.0001)$.Association of control male and Beta thalassemic male vs. Palmar atd angle left was statistically significant $(\mathrm{p}<0.0001)$.

Our study showed that association of control and Beta thalassemic female vs. Palmar atd angle right was statistically significant $(p<0.0001)$.Association of control and Beta thalassemic female vs. Palmar atd angle left was statistically significant $(\mathrm{p}<0.0001)$. Association of control female and Beta thalassemic male vs. Palmar atd angle right was statistically significant $(\mathrm{p}<0.0001)$. Association of control female and Beta thalassemic male vs. Palmar atd angle left was statistically significant $(\mathrm{p}<0.0001)$. Association of control and Beta thalassemia vs. Pattern intensity index right was statistically significant $(\mathrm{p}=.012)$.Association of control and Beta thalassemia vs. Pattern intensity index left was statistically significant $(\mathrm{p}<0.0001)$ Association of control male and Beta thalassemic male vs. Pattern intensity index right was statistically significant $(\mathrm{p}<0.0001)$. Association of control male and Beta thalassemic male vs. Pattern intensity index left was statistically significant $(\mathrm{p}<0.0001)$.

We also found that association of control and Beta thalassemic female vs. Pattern intensity index right was statistically significant $(\mathrm{p}=.008)$.Association of control and Beta thalassemic female vs. Pattern intensity index left was statistically significant $(\mathrm{p}<0.0001)$. Association of control male and Beta thalassemic female vs. Pattern intensity index right was statistically significant $(p=.012)$. Association of control male and Beta thalassemic female vs. Pattern intensity index left was statistically significant $(\mathrm{p}<0.0001)$. Association of control and Beta thalassemia vs. total Finger Ridge Count right was not statistically significant $(p=.125)$. Association of control and Beta thalassemia vs. total Finger Ridge Count left was statistically significant $(\mathrm{p}<0.0001)$. Association of control male and Beta thalassemic male vs. total Finger Ridge Count right was statistically significant $(\mathrm{p}=.048)$.Association of control male and Beta thalassemic male vs. total Finger Ridge Count left was statistically significant $(\mathrm{p}<0.0001)$.

It was found that association of control and Beta thalassemic female vs. Total Finger Ridge Count right was statistically significant $(p=.004)$.Association of control and Beta thalassemia female vs. total Finger Ridge Count left was statistically significant $(p<0.0001)$. Association of control female and Beta thalassemic male vs. Total Finger Ridge Count right was not statistically significant $(\mathrm{p}=.125)$. Association of control female and Beta thalassemic male vs. Total Finger Ridge Count left was statistically significant $(\mathrm{p}<0.0001)$

\section{DISCUSSION}

In our study, 204 individuals were included and divided into two 
groups. The first group comprised of 102 diagnosed Beta thalassemia patients (Male $=51$, Female $=51$ ) upto $12 \mathrm{yrs}$ of age with relevant hematologic evidence were selected as cases. On the other hand, the second group comprised of normal children up to $12 \mathrm{yrs}$ of age without any hemoglobinopathy and positive family history of hemoglobinopathy which were selected as control group. The dermatoglyphic pattern of these two groups were compared on basis of qualitative parameters (like arches, loops, whorls) and quantitative parameters (like Total Finger Ridge Count, a-b Ridge count, Triradial count, Pattern Intensity index and Palmar atd angle).The data obtained were tabulated and subjected to statistical analysis. Thus, a specific correlation was found between dermatoglyphic pattern and Beta thalassemia.

In our present study, there was an increase in frequency of arch patterns of right hand among Beta thalassemia patients as compared to the control group and was statistically highly significant. There was a significant higher incidence of arch patterns of right hand in Beta thalassemic females than their respective control group. The significant increase in frquency of this pattern was also evident in Beta thalassemic females than Beta thalassemic males. Dehankar et.al ${ }^{5}$ and Bhalla et.al ${ }^{6}$ observed significant higher incidence of arches in Beta thalassemics than controls in their study.

In our study, there was complete absence of radial loops among Beta thalassemic females. But, it was present in Beta thalassemic males. The findings were the same with Rosner and Spriggs ${ }^{7}$. Ulnar loops were increased in frequency in Beta thalassemic females as compared to Beta thalassemic males. An increase in incidence of ulnar loop patterns of right hand in female thalassemia patients was observed, than their respective control group.Among Beta thalassemic males, this epidermal ridge pattern was decreased in frequency in both hands than their control group. There was an increase in incidence of whorl pattern of both hands in thalassemia patients than the control group, which was statistically insignificant.This favours the findings of Rosner and Spriggs $^{7}$; and Saha et.al ${ }^{8}$. as they observed higher incidence of whorl with decreased frequency of loops of either sex. Multilova et.al ${ }^{9}$ also observed slightly raised incidence of whorl pattern in their study.

In our study, we have found higher value of mean a-b Ridge count among thalassemia patients as compared to the control group.But, it was significantly higher in case of male Beta thalassemics than the male control group. Dehankar et.al ${ }^{5}$, Mehta et. $\mathrm{al}^{10}$ and Bhalla et.al ${ }^{6}$ also had found higher mean a-b Ridge count in Beta thalassemic patients than their control group.

Regarding Pattern Intensity Index(P.I.I),we have found statistically significant increase of mean P.I.I in Beta thalassemia patients than control groups.In relation to sex, we have found significant increase of mean P.I.I in males and decreased in females. In1969, Rosner and Spriggs $^{7}$ had observed negligible fall of mean P.I Index in male, while in female it was slightly raised, different from our finding.

Saha et. $\mathrm{Al}^{8}$ and Mehta et.al ${ }^{10}$ had analysed the dermatoglyphic patterns in Beta thalassemia patients and control groups in their comparative study. They had observed that mean triradial counts were higher in both the sexes than their controls. Similar results were obtained in our current study, where mean triradial counts were higher in both sexes than their control groups and the values were statistically highly significant.

Rosner and Spriggs ${ }^{7}$ had observed an insignificant higher value of Total Finger Ridge Count(T.F.R.C) in case of Cooley $s$ anemia. In our study, we have found that the Beta thalassemia patients show statistically significant lower value of left T.F.R.C and insignificant lower value of right T.F.R.C than the control individuals. The mean T.F.R.C value is lower in our study, irrespective of sex. Dallapiccola ${ }^{1}$ in his study of dermatoglyphic change in thalassemia patients, of Italian population, had found significant lower values of mean in T.F.R.C.

In our study, there was higher incidence of Palmar atd angle among Beta thalassemia patients in respect to the control group which was statistically highly significant. In relation to sex, there was significant increase in mean Palmar atd angle in Beta thalassemia patients than their respective control individuals. However,in the study statistically significant higher value of mean atd angle was observed in female Beta thalassemia patients in respect to their male counterparts. Multilova et.al ${ }^{9}$, Dallapiccola et.al ${ }^{11}$, Dehankar et.al ${ }^{5}$, Mehta et.al ${ }^{10}$ had found in their study, higher value of mean Palmar atd angle in Beta thalassemia patients than the control group, which favours the findings of our study. Bilateral asymmetry, were observed in case of arch, loops, a-b Ridge Count, Triradial count, Pattern intensity index, Total Finger Ridge Count, Palmar atd angle. Regarding Bilateral asymmetry, we have observed significant statistical difference in these mentioned parameters.

The importance of this study with the knowledge of dermatoglyphic pattern in Beta thalassemia is that, it becomes an imperative for the clinicians to have the basic awareness of a dermatoglyphic pattern of the disease. So that patients are informed and warned to make early diagnosis of these patients, thereby helping in early initiation of treatment and blood transfusion.

\section{CONCLUSION}

In the present case control study we have considered a total 102 Beta thalassemia patients. Out of them, 51 were males and 51 were females. We have also considered sex matched control groups. Both the digital and palmar prints were taken to make observations of different parameters. By the help of these observations, dermatoglyphic changes in Beta thalassemia patients were compared with the control groups. The comparisons were made irrespective of sex and also in relation to sex. Furthermore, we have observed whether there was any variation of dermatoglyphics among thalassemia patients, in relation to sex.

In our present study, the following conspicuous features were found in thalassemia patients:

In our observation regarding digital dermatoglyphics,

It was found that there was higher incidence of arches in Beta thalassemia patients, irrespective of sex. But, when compared in relation to sex, increase in frequency of arch patterns of right hand were observed in both sexes as compared to their sex matched control groups. There was increased frequency of arches in female patients than male patients. All these observations of arch patterns were statistically highly significant.

In female thalassemia patients, there was complete absence of radial loops. But, significant lower incidence of radial loops of left hand was observed in male Beta thalassemics than the control group.

In palmar dermatoglyphics,

Mean value of $a-b$ Ridge count of right hand was significantly higher in Beta thalassemia patients than the control group. When compared in relation to sex, there was a significant increase of mean a-b Ridge count in male thalassemics than their control group.

Regarding Pattern Intensity Index(P.I.I),we have found statistically significant higher value of mean P.I.I in Beta thalassemia patients than control groups. In relation to sex, we found significant higher value of mean P.I.I in males and lower value in females. The mean triradial counts were higher in both sexes than their control groups and the values were statistically highly significant. The thalassemia patients show statistically significant lower value of left T.F.R.C than the control individuals.

We have observed, a higher value of mean Palmar atd angle among Beta thalassemia patients in respect to the control group which was statistically highly significant. In relation to sex, there was a significant increase of mean Palmar atd angle in Beta thalassemia patients than the respective control individuals. However, in the study statistically significant higher value of mean atd angle was observed in female Beta thalassemia patients in respect to their male counterparts.

Bilateral asymmetry, were observed in case of arch, loops, a-b Ridge Count, Triradial count, Pattern Intensity index, Total Finger Ridge Count, Palmar atd angle. Regarding Bilateral asymmetry, we have observed significant statistical difference in these mentioned parameters.

From our case control study,it is evident that there are some statistically significant changes among the Beta thalassemia patients which may be useful in population genetics. For individual diagnosis of Beta thalassemia with the help of digital and palmar dermatoglyphics, we need further more extensive studies in future. 


\section{REFERENCE}

Penrose L. S and Ohara P. T: The development of epidermal ridges. Journal of medical genetics. 1973; 10:p. 201-208

Cummins, H. Dermatoglyphic stigmata in Mongolian idiocy, Anat. Rec.1936; 64:p.11 Thein SL.: Genetic modifiers of thalassemia, Hematologica. 2005; 90:p. 649-660.

4. Cooley, T.B; Witwer, E.R., and Lee, Pearl;Anemia in Children with Splenomegaly and Peculiar changes in Bones: Report of Cases, Am. J. Dis. Child. (Sept) 1927; 34:p. 347-363.

5. Dehankar, R. N., \& Ksheersagar, D. D. Study of Dermatoglyphic Patterns in Thalassemia. Proceedings of 50th National conference of Anatomical Society of India, Kochi, 28-30 December 2006; Abstract 246:p. 160-176. Kochi, 28-30Decer 2006, Abstract 246.p.160-176.

. Bhalla, A. K., Manwala, R. K., Kaur, H., \& Sharma, A. :Finger and Paln Dermatoglyphics in Beta Thalassemia Patients. Mank Q: Sring 2007;30:p. 125-130.

7. Rosner, F. And Spriggs, H.A. : Dermatoglyphic studies in patients with Cooley s anemia, Ann. N. Y.Acad. Sci. 1969; 1: p.165-378.

8. Saha, K. C., Chatterjee, J. B., \& Mukherjee, D. P. : Dermatoglyphics in Thalassemia Syndrome. Journal of Indian Medical Association.1973; 61:p. 205-211

9. Mutalimova A.B., Kurdiumova TIu. Dermatoglyphics in betathalassemia major. Genetika. 1975; 11:p. 150-51.

10. Mehta L, Mahajan A.S., Naidu S.S.; Study of Palmar Dermatoglyphics in Thalassemia, Abstracts book 56 th National conference of Anatomical Society of India. 2008;p. 95.

11. Dallapiccola D, Capra L, Baricordi O, Mazilli C. :Dermatoglyphic studies in patients with Cooley's anemia and Cooley's trait. Acta Genet Med Gemellol. (Roma.) 1975; 24 : p.283-93. 